\title{
PENGARUH ORIENTASI BELANJA DAN KUALITAS PRODUK TERHADAP MINAT BELI BELANJA ONLINE JD.ID JAKARTA
}

\author{
Jonatan \\ UniSadhuGuna Business School \\ Email: jonatan_nsp@yahoo.co.id
}

\begin{abstract}
Begin from early survey that shows how online business is growing rapidly at this time, such thing has stimulates me to do research about factors that affecting online business, particularly for online shopping consumer. I has limited time, then this research only focus on two factors that considered affecting the interest of online shopping, those two factors are the affect of shopping orientation and product quality toward buying interest of online shopping. The source of this research is from pleaded questionnaire to 50 respondents. The research is using descriptive quantitative method. Through data analysis by using SPSS instrument. The result shows the truth of hypothesis that each of shopping orientation and product quality affect partially toward buying interest of online shopping and affect simultaneously as well.
\end{abstract}

Keywords: shopping orientations; quality product; online purchase

\section{Pendahuluan}

Seiring perkembangan zaman, persaingan pasar semakin hari terasa semakin ketat dengan semakin banyaknya penjual pendatang baru yang mencoba masuk ke dalam pasar dengan jenis produk yang sama. Dengan semakin majunya teknologi komunikasi, segala sesuatu informasi semakin mudah diperoleh masyarakat melalui jaringan internet. Kemajuan teknologi komunikasi dan informasi online telah semakin dimanfaatkan oleh para penjual produk yang ingin menginformasikan produknya secara cepat dan murah kepada masyarakat yang semakin luas pula. Hal ini mendorong terjadinya semacam revolusi cara berbelanja. Ada pergeseran cara orang untuk membeli suatu barang atau jasa, yang bisa mengatasi kendala waktu dan jarak. Pencarian informasi merupakan tahap penting dalam model pengambilan keputusan konsumen. Internet dapat mempermudah pencarian online dan pembelian aktual (Nam, 2003:40).

Bagi konsumen online, pencarian informasi tersebut bisa didapat melalui search engine di internet, atau dengan berkeliling keluar masuk toko. Informasi yang dikumpulkan bisa berupa harga, merek, spesifikasi barang, bentuk, bahan material, dan lain-lain yang selanjutnya akan dijadikan bahan pertimbangan konsumen untuk melakukan pembelian. Perkembangan Internet juga telah mempengaruhi perkembangan ekonomi. Teknologi ini dimanfaatkan sebagai sarana proses jual beli yang didukung dengan perangkat elektronik, terutama internet ini dikenal dengan nama e-commerce (Kotler \&Armstrong, 2010). 
Pemilik akun online shop pada blog, web dapat dengan mudah untuk mempromosikan barang yang di jual, hanya upload foto dan menandai foto tersebut ke semua friendlist secara random. Setelah itu, tidak lupa mereka mencantumkan harga, bahan dasar, kualitas dari barang yang dijual serta bagaimana cara pemesanan dan pembayarannya. Karena berbelanja online melalui facebook dianggap sudah cukup efisien, mereka tidak perlu keluar dari rumah jika ingin membeli barang yang diinginkan. Hal ini tidak terlepas dari persepsi konsumen terhadap kualitas produk yang akan membentuk prefensi dan sikap yang pada gilirannya akan mempengaruhi minat dan keputusan membeli atau tidak. perilaku konsumen menurut Shiffman, dan Kanuk (2000) adalah proses yang dilalui oleh seseorang dalam mencari, membeli, menggunakan, mengevaluasi dan bertindak pasca konsumsi produk, jasa maupun ide yang diharapkan bisa memenuhi kebutuhannya (Sugiono, 2006).

Belakangan ini e-commerce kembali berkembang dan menyita perhatian penduduk Indonesia, padahal e-commerce sudah ada di Indonesia sejak tahun 1995. Menurut Kotler \& Keller (2012) e-commerce merupakan pemanfaatan website dengan dukungan internet sebagai sarana menjual produk maupun jasa. Dengan tidak adanya biaya sewa tempat untuk usaha, pemanfaatan website dapat mendatangkan keuntungan dengan menjual produk dengan kuantitas tertentu pada pangsa pasar khusus. Perkembangan dan pemanfaatan e-commerce tidak terlepas dari bergesernya orientasi belanja masyarakat pada saat ini. Seock \& Bailey (2008) mengakui ada 7 orientasi belanja, yaitu:

a. Shopping enjoyment, pembeli pada segmen ini menikmati transaksi pembelian tidak hanya untuk produk yang dibeli, tetapi demi pengalaman itu sendiri.

b. Brand and fashion conscious shopper, mencari merek-merek terkenal dan lebih trendi

c. Price conscious, adalah pembeli yang mencari harga produk yang lebih rendah

d. Shopping confidence, adalah pembeli yang yakin pada kemampuan mereka untuk menjadi pembeli yang bijaksana

e. Convenience/time conscious, lebih mencari transaksi pembelian yang membuat mereka nyaman

f. In-home shopping, adalah pembeli yang lebih suka berbelanja dari rumah

g. Brand/store loyalty, yang menujukkan para pembeli yang setia terhadap merek tertentu.

Selain adanya orientasi belanja masyarakat yang bergeser saat ini, terdapat elemen lain yang dapat mempengaruhi seseorang dalam melakukan pembelajaan secara online melalui e-commerce, yaitu dengan melihat faktor kualitas produk. Produk menurut Kotler (2009) adalah segala sesuatu yang dapat ditawarkan kepasar untuk mendapatkan perhatian, dibeli, digunakan, atau dikonsumsi yang dapat memuaskan keinginan atau kebutuhan. Produk dapat pula didefinisikan sebagai persepsi konsumen yang dijabarkan oleh produsen melalui hasil produksinya (Tjiptono, 2008).

Baik kualitas produk dan orientasi belanja dengan 7 faktor yang dimilikinya dapat dilihat kecenderungan pergeseran gaya belanja konsumen apakah dapat 
mempengaruhi minat belanja online yang menurut Howard (1994) ( Durianto dan Liana, 2004:44) merupakan sesuatu yang berhubungan dengan rencana konsumen untuk membeli produk tertentu serta berapa banyak unit produk yang dibutuhkan pada periode tertentu. JD.ID sebagai salah satu online mall terbesar di Indonesia yang memiliki induk perusahaan raksasa sebelumnya di Tiongkok, menyediakan berbagai macam produk pilihan dari elektronik, household, aksesoris, luxury dan lain-lain. Model bisnis yang dianut JD merupakan B2C (Business to Consumer), yang berarti JD sendirilah yang mengadakan stok barang yang nantinya akan dijual dilayanan mereka.

Manajemen pemasaran adalah menganalisa, merencanakan, mengimplementasikan, dan mengawasi segala kegiatan (program), guna memperoleh tingkat pertukaran yang menguntungkan dengan pembeli sasaran dalam rangka mencapai tujuan organisasi (Alma, 2005;130).

Definisi diatas menekankan adanya efektifitas dan efisiensi. Efektivitas artinya memaksimalkan hasil yang hendak dicapai yang telah ditetapkan lebih dahulu. Sedangkan efisiensi adalah meminimalkan pengeluaran lebih dahulu, sedangkan efisiensi adalah meminimalkan pengeluaran atau biaya yang digunakan untuk mencapai hasil tersebut (Alma, 2005;130).

Perilaku konsumen adalah suatu proses dan aktivitas dimana individu atau sekelompok orang melakukan pemilihan, pembelian, penggunaan atau membuang suatu produk, jasa, ide atau sebuah pengalaman untuk memuaskan keinginan dan kebutuhan mereka.

Kotler \& Keller (2012) mengemukakan e-commerce merupakan pemanfaatan website dengan dukungan internet sebagai sarana menjual produk maupun jasa.

\section{Metode Penelitian}

Penelitian ini menggunakan metode deskriptif kuantitatif. Dengan menyebarkan kuesioner kepada 50 responden penelitian ini menggunakan pendekatan sensus, yang pengolahan datanya menggunakan software SPSS 22.

Hipotesis:

1. Diduga Orientasi Belanja berpengaruh secara parsial terhadap minat belanja Online?

2. Diduga Kualitas Produk berpengaruh secara parsial terhadap minat belanja Online?

3. Diduga Orientasi Belanja dan Kualitas Produk Berpengaruh secara simultan terhadap minat belanja Online?

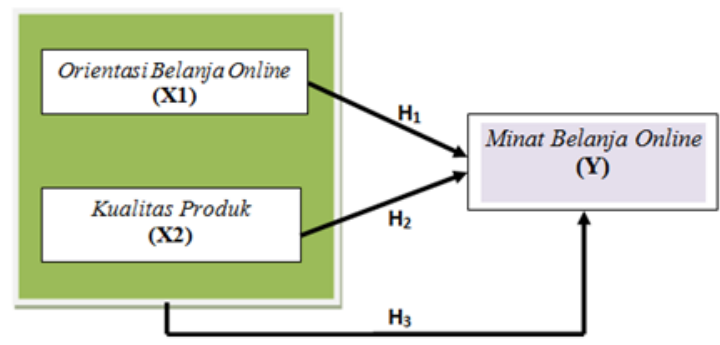


Keterangan :

$\begin{array}{ll}\longrightarrow & =\begin{array}{c}\text { Pengaruh } \\ \text { variable }\end{array} \\ \mathrm{H}_{1} & =\text { Pengaruh }\left(\mathrm{X}_{1}\right) \text { terhadap } \mathrm{Y} \\ \mathrm{H}_{2} & =\text { Pengaruh }\left(\mathrm{X}_{2}\right) \text { terhadap } \mathrm{Y} \\ \mathrm{H}_{3} & =\text { Pengaruh }\left(\mathrm{X}_{1}, \mathrm{X}_{2}\right) \text { terhadap } \mathrm{Y}\end{array}$

\section{Hasil dan Pembahasan}

1. Uji Validitas

Tabel 1 Uji ValiditasVariabel Orientasi Belanja $\left(\mathbf{X}_{1}\right)$

\begin{tabular}{cccc}
\hline \multirow{2}{*}{ Pernyataan } & \multicolumn{3}{c}{ Orientasi Belanja( $\left.\mathbf{X}_{\mathbf{1}}\right)$} \\
\cline { 2 - 4 } & rabel $\mathbf{n}=$ & \\
& rhitung & $\mathbf{5 0}$ & Keterangan \\
\hline 1 & 0.781 & 0.2732 & Valid \\
\hline 2 & 0.807 & 0.2732 & Valid \\
\hline 3 & 0.732 & 0.2732 & Valid \\
\hline 4 & 0.764 & 0.2732 & Valid \\
\hline 5 & 0.659 & 0.2732 & Valid \\
\hline 6 & 0.392 & 0.2732 & Valid \\
\hline 7 & 0.690 & 0.2732 & Valid \\
\hline 8 & 0.340 & 0.2732 & Valid \\
\hline 9 & 0.642 & 0.2732 & Valid \\
\hline 10 & 0.380 & 0.2732 & Valid \\
\hline 11 & 0.362 & 0.2732 & Valid \\
\hline 12 & 0.617 & 0.2732 & Valid \\
\hline 13 & 0.335 & 0.2732 & Valid \\
\hline 14 & 0.330 & 0.2732 & Valid \\
\hline 15 & 0.509 & 0.2732 & Valid \\
\hline 16 & 0.168 & 0.2732 & Valid \\
\hline 17 & 0.275 & 0.2732 & Valid \\
\hline 18 & 0.309 & 0.2732 & Valid \\
\hline & & &
\end{tabular}

Berdasarkan tabel 1, dapat dilihat bahwa untuk masing-masing pernyataan pada variabel kualitas Informasi $\left(\mathrm{X}_{1}\right)$ seluruh instrument dapat dikatakan valid, karena nilai $r_{\text {hitung }}$ yang dihasilkan jauh lebih besar dari pada nilai $r_{\text {tabel }}$ yang ada untuk $\mathrm{n}=50($ Lima Puluh $)=0,2732$.

Tabel 2 Uji Validitas Variabel Kualitas Produk (X2)

\begin{tabular}{cccc}
\hline \multirow{2}{*}{ Pernyataan } & \multicolumn{3}{c}{ Kualitas Produk $\left(\mathbf{X}_{2}\right)$} \\
\cline { 2 - 4 } & $\mathbf{r}_{\text {hitung }}$ & $\mathbf{r}_{\text {tabel } \mathbf{n}=\mathbf{5 0}}$ & Keterangan \\
\hline 1 & 0.620 & 0.2732 & Valid \\
\hline 2 & 0.804 & 0.2732 & Valid \\
\hline 3 & 0.680 & 0.2732 & Valid \\
\hline 4 & 0.609 & 0.2732 & Valid \\
\hline 5 & 0.650 & 0.2732 & Valid \\
\hline
\end{tabular}


Berdasarkan Tabel 2, dapat dilihat bahwa untuk masing- masing pernyataan pada variabel Kualitas $\operatorname{Produk}\left(\mathrm{X}_{2}\right)$ seluruh instrument dapat dikatakan valid, karena nilai $r_{\text {hitung }}$ yang dihasilkan jauh lebih besar dari pada nilai $r_{\text {tabel }}$ yang ada untuk $n=50$ (lima puluh) yaitu 0.2732 .

\begin{tabular}{|c|c|c|c|}
\hline \multirow{2}{*}{ Pernyataan } & \multicolumn{3}{|c|}{ Minat Belanja(Y) } \\
\hline & rhitung & $\begin{array}{c}\mathbf{r}_{\text {tabel }}= \\
\quad 50\end{array}$ & Keterangan \\
\hline 1 & 0.806 & 0.2732 & Valid \\
\hline 2 & 0.761 & 0.2732 & Valid \\
\hline 3 & 0.594 & 0.2732 & Valid \\
\hline 4 & 0.687 & 0.2732 & Valid \\
\hline
\end{tabular}

Berdasarkan tabel 3, dapat dilihat bahwa untuk masing-masing pernyataan pada variabel Minat Belanja (Y) seluruh instrument dapat dikatakan valid, karena nilai $r_{\text {hitung }}$ yang dihasilkan jauh lebih besar dari pada nilai $r_{\text {tabel }}$ yang ada untuk $n=50$ (lima puluh) yaitu 0.2732 .

\section{Tabel 4 Uji Reliabilitas Variabel Orientasi Belanja $\left(\mathbf{X}_{1}\right)$}

Reliability Statistics

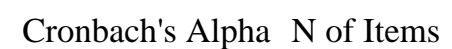

$$
\text { Sumber : Hasil Olahan data (SPSS 22) }
$$

Berdasarkan tabel di atas ini, untuk uji reliabilitas variabel kualitas Informasi $\left(\mathrm{X}_{1}\right)$ dengan nilai Cronbach's Alpha sebesar 0.839, sehingga dapat disimpulkan instrument penelitian mengenai variabel kualitas Informasi $\left(\mathrm{X}_{1}\right)$ adalah Reliabel.

\section{Tabel 5 Uji Reliabilitas Variabel Kualitas Produk $\left(\mathbf{X}_{2}\right)$}

Reliability Statistics

\begin{tabular}{cr}
\hline Cronbach's Alpha & N of Items \\
\hline .675 & 5 \\
\hline
\end{tabular}

Dari tabel 5, untuk uji reliabilitas variabel Kualitas Produk $\left(\mathrm{X}_{2}\right)$ dengan nilai Cronbach's Alpha sebesar 0.675, sehingga dapat disimpulkan bahwa instrumen penelitian mengenai variabel kualitas produk $\left(\mathrm{X}_{2}\right)$ adalah Reliabel.

\section{Tabel 6 Uji Reliabilitas Variabel Minat Belanja Online (Y)}

\begin{tabular}{cr}
\hline \multicolumn{2}{c}{ Reliability Statistics } \\
\hline $\begin{array}{c}\text { Cronbach's } \\
\text { Alpha }\end{array}$ & $\begin{array}{c}\mathrm{N} \\
\text { of Items }\end{array}$ \\
\hline .673 & 4 \\
\hline
\end{tabular}


Berdasarkan tabel 6, untuk uji reliabilitas variabel Minat Belanja (Y) dengan nilai Cronbach's Alpha sebesar 0.673, sehingga dapat disimpulkan bahwa instrumen penelitian mengenai variabel minat beli (Y) adalah Reliabel.

Tabel 7 Hasil Uji Normalitas Data

\begin{tabular}{llr}
\hline \multicolumn{3}{c}{ One-Sample Kolmogorov-Smirnov Test } \\
\hline $\mathrm{N}$ & \multicolumn{2}{c}{ Standardized Residual } \\
\hline Normal Parameters ${ }^{\mathrm{a}, \mathrm{b}}$ & Mean & 50 \\
\cline { 2 - 3 } & Std. Deviation & .0000000 \\
\hline Most Extreme & Absolute & .97937923 \\
\cline { 2 - 3 } Differences & Positive & .060 \\
\cline { 2 - 3 } & Negative & .058 \\
\hline Test Statistic & & -.060 \\
\hline Asymp. Sig. (2-tailed) & & .060 \\
\hline \multicolumn{2}{l}{ a. Test distribution is Normal. } & $.200^{\mathrm{c}, \mathrm{d}}$ \\
\hline \multicolumn{2}{l}{ b. Calculated from data. } & \\
\hline
\end{tabular}

Berdasarkan tabel 7, nilai signifikansi (2-tailed) sebesar 0.200, dapat diartikan bahwa nilai signifikansi (2-tailed) alat ukur tersebut berada di atas 0.05 sehingga data dikatakan berdistribusi normal. Sedangkan nilai Kolmogorov-Smirnov sebesar 0.600, berarti data residual terdistribusi normal.

Tabel 8 Uji Multikolinearitas

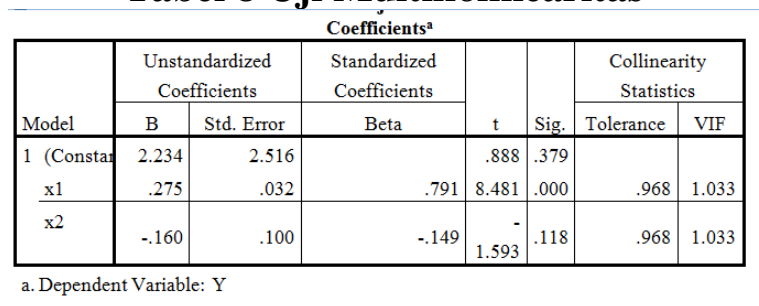

Berdasarkan tabel 8, dapat diketahui bahwa nilai Variance Inflation Factor (VIF) dari masing - masing variabel independent tidak memiliki nilai yang lebih dari 10, sehingga dapat disimpulkan bahwa model regresi dalam penelitian ini tidak mengandung multikolinierita

Tabel 9 Uji Heteroskedastisitas

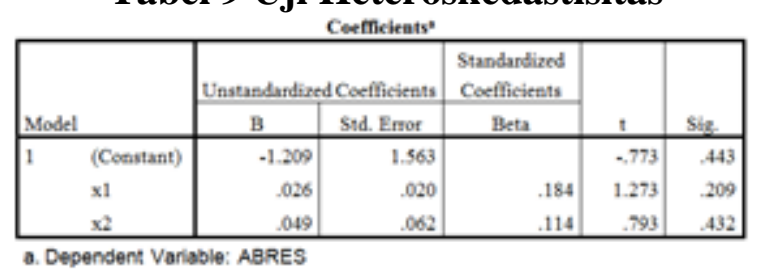

Hasil uji heteroskedastisitas dengan menggunakan metode Glajser ini, semua Variabel independen signifikan pada $>0.05$ hal ini menunjukan tidak terjadi gejala heteroskedastisitas pada model regresi. 


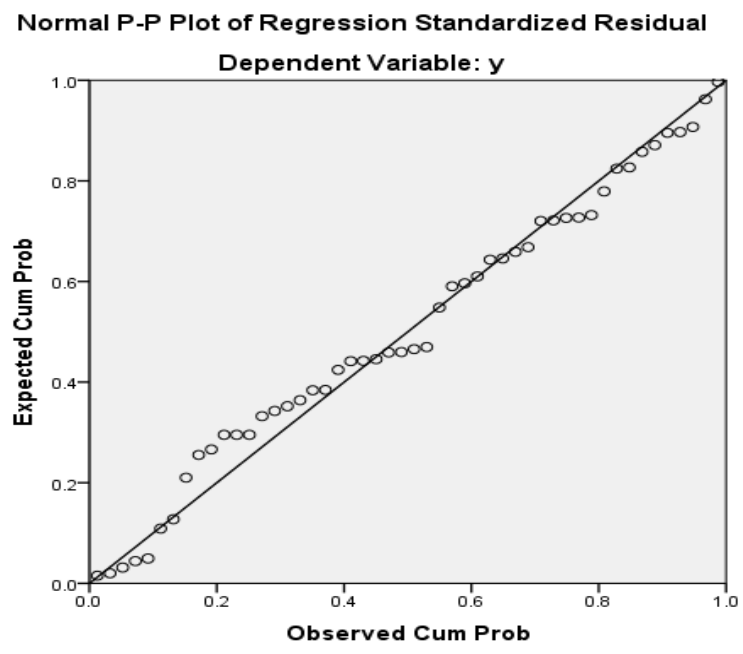

Gambar 1 Uji Linieritas

Berdasarkan gambar di atas dapat diketahui bahwa titik-titik membentuk pola yang jelas, titik-titik residualnya bertebar mengikuti garis diagonal maka dapat disimpulkan model regresi yang digunakan linear.

2. Pengujian Hipotesis

a. Analisis Linear Berganda

Tabel 10 Hasil Analisis Linier Berganda

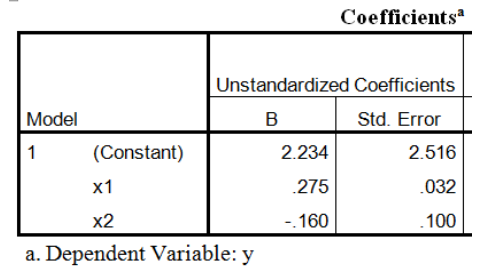

Untuk menentukan nilai persamaan regresi linear bergandanya sebagai berikut: $\left.Y^{\prime}=\mathbf{2 . 2 3 4}+\mathbf{0 . 2 7 5} \mathrm{X}_{\mathbf{1}}+\mathbf{( - \mathbf { 0 . 1 6 0 X }} \mathbf{X}_{2}\right)$. Dapat dijelaskan sebagai berikut:

1. Jika nilai konstanta naik sebesar 1 satuan dengan asumsi variabel Orientasi belanja online $\left(\mathrm{X}_{1}\right)$ dan variabel kualitas produk $\left(\mathrm{X}_{2}\right)$ tetap, maka nilai variabel minat belanja (Y) akan naik sebesar 2.234

2. Nilai koefisien regresi variabel orientasi belanja online $\left(\mathrm{X}_{1}\right)$ terhadap variabel minat belanja online (Y) adalah sebesar 0.275 . Hal ini berarti jika variabel orientasi belanja online $\left(\mathrm{X}_{1}\right)$ naik 1 satuan akan meningkatkan variabel minat belanja online (Y) sebesar 0.275.

3. Nilai koefisien regresi variabel Kualitas $\operatorname{produk}\left(\mathrm{X}_{2}\right)$ terhadap variabel minat belanja online $(\mathrm{Y})$ adalah sebesar $-0.160 \mathrm{Hal}$ ini berarti jika variabel kualitas produk $\left(\mathrm{X}_{2}\right)$ menaikkan 1 satuan akan menaikkan variabel minat belanja online (Y) sebesar -0.160 , dengan asumsi variabel orientasi belanja online $\left(\mathrm{X}_{1}\right)$ dan konstanta tidak berubah. 
b. Uji T

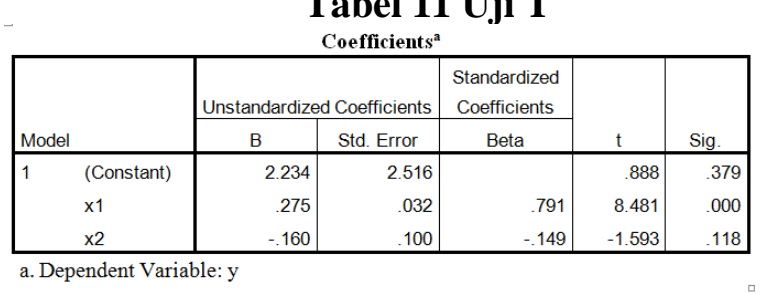

a) Hubungan Variabel Orientasi Belanja Online $\left(\mathrm{X}_{1}\right)$ dengan Minat Belanja Online (Y)

Hasil tabel coefficients di atas dengan menggunakan perhitungan análisis SPSS Versi 22.00, maka nilai thitung untuk variabel $\mathrm{X}_{1}$ (orientasi belanja online) sebesar 8.481, sedangkan nilai $t_{\text {tabel }}$ untuk $\mathrm{n}=50$ sebesar 2.008. Jadi $8.481>2.008$, dapat disimpulkan bahwa secara parsial variabel Orientasi belanja online $\left(\mathrm{X}_{1}\right)$ berkorelasi terhadap Minat belanja online $(\mathrm{Y})$.

b) Hubungan Variabel Kualitas Produk $\left(\mathrm{X}_{2}\right)$ dengan Minat Belanja Online (Y)

Jika diperhatikan hasil tabel coefficients di atas dengan menggunakan perhitungan 63nálisis SPSS Versi 22.00, maka nilai thitung untuk variabel $\mathrm{X}_{2}$ (Kualitas Produk) sebesar -1.593 , sedangkan nilai tabel untuk $\mathrm{n}=50$ sebesar 2.008. Jadi $-1.593>2.008$, dapat disimpulkan bahwa secara parsial variabel Kualitas Produk $\left(\mathrm{X}_{2}\right)$ berkorelasi terhadap Minat Belanja Online $(\mathrm{Y})$.

c. Uji Anova

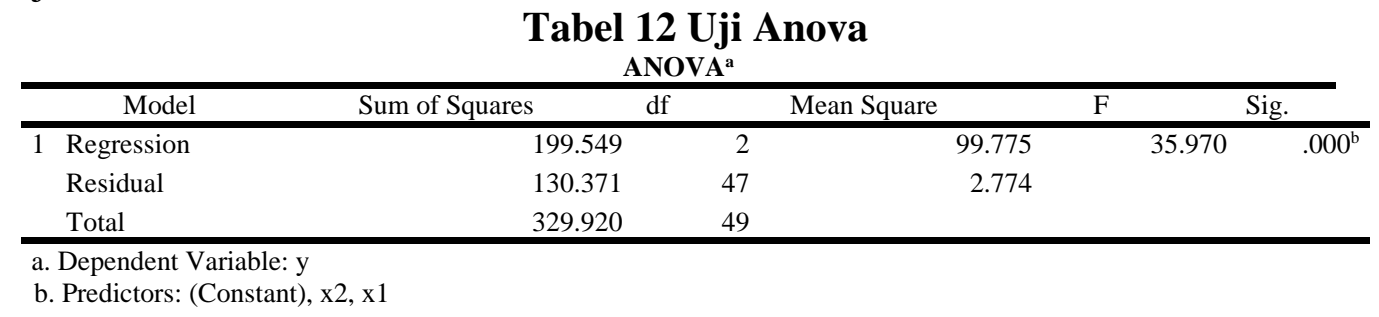

Dari hasil uji ANOVA atau $f_{\text {hitung }}$ didapat nilai $f_{\text {hitung }}$ sebesar 35.970 dimana lebih besar dari nilai $f_{\text {tabel }}$ untuk $n=50$ sebesar 2.008 atau 35.970>3.18 dengan tingkat signifikan sebesar 0,000 karena $0,000<0,05$, maka dapat dikatakan Orientasi belanja online $\left(\mathrm{X}_{1}\right)$ dan Kualitas Produk $\left(\mathrm{X}_{2}\right)$ secara bersama-sama mampu menjelaskan Minat Belanja Online (Y) pada $\alpha=5 \%$.

d. Koefisien Determinasi

Tabel 13 Hasil Koefisien Determinasi

Model Summary

\begin{tabular}{|c|c|c|c|c|}
\hline \multicolumn{5}{|c|}{ Model Summary } \\
\hline Model & $\mathrm{R}$ & R Square & $\begin{array}{c}\text { Adjusted R } \\
\text { Square }\end{array}$ & $\begin{array}{l}\text { Std. Error of } \\
\text { the Estimate }\end{array}$ \\
\hline 1 & $.778^{\mathrm{a}}$ & .605 & .588 & 1.66549 \\
\hline
\end{tabular}

Predictors: (Constant), $\mathrm{x} 2, \mathrm{x} 1$

Dependent variable: $Y$

Berdasarkan pada tabel 13 yakni Model Summary yang menghasilkan nilai R Square sebesar 0.605, artinya bahwa kualitas Informasi dan sistem informasi 
manajemen secara bersama-sama mampu menjelaskan variabel kinerja karyawan sebesar $57.8 \%$ sedangkan sisanya sebesar $42.2 \%$ adalah faktor-faktor lain yang tidak diteliti dalam penelitian ini.

\section{Kesimpulan}

berikut ini akan penulis sampaikan kesimpulan dari pembahasan pada bab sebelumnya.

1. Benar bahwa secara parsial variabel orientasi belanja online (X1) berkorelasi positif signifikan terhadap minat belanja online (Y) pada $\alpha=5 \%$ hal tersebut dapat dibuktikan dari thitung untuk variabel X1 (Minat Belanja Online) sebesar 8.841, sedangkan nilai ttabel untuk $\mathrm{n}=50$ sebesar 2.008. Jadi $8.841>2.008$.

2. Benar bahwa secara parsial variabel kualitas produk (X1) berkorelasi positif signifikan terhadap minat belanja online (Y) pada $\alpha=5 \%$ hal tersebut dapat dibuktikan dari nilai thitung untuk variabel X2 (kualitas produk) sebesar -1,593, sedangkan nilai ttabel untuk $\mathrm{n}=50$ sebesar 2.008. Jadi $-, 1593>2,008$.

3. Benar bahwa orientasi belanja online dan produk kualitas secara bersamasama/simultan berkorelasi dengan minat belanja online (Y) pada $\alpha=5 \%$ hal tersebut dapat dilihat dari nilai Fhitung sebesar 35.970, sedangkan nilai Ftabel untuk $\mathrm{n}=50$ sebesar 3.18. Jadi 35.970>3.18. 


\section{DAFTAR PUSTAKA}

Capitalizing on the Value of BrandName”, The Free Press, New York, 1991

Amaliya, Ulya, "E-Commerce di Singapura dan Indonesia: Sebuah Perbandingan Kebijakan", dari http://ulyaamaliya.

Bearden et al., (2001). Marketing: Principles and Perspectives Third Edition. McGrawHill

Chandrataruna, Muhammad, “47\% Masyarakat Pernah Transaksi Online”, diakse pada 2 Maret 2017,

dari http://www.viva.co.id/cangkang/ramadhan2013/news/read/152786-47masyarakat-pernah-transaksi-online

Durianto. (2005). "Strategi Menaklukkan Pasar Melalui Riset Ekuitas dan PerilakuMerek”, PT. Gramedia Pustaka Utama, Jakarta

Garry, "Sejarah Toko Online", diakses pada tanggal 21 Agustus 2013 dari http://www.computesta.com/blog/2012/03/sejarah-tokoonline/\#.USN5a6XIs9R

Gehrt dan Shim, (1998) "A shopping Orientation Segmentation of French Consumers:Implications for Catalog Marketing”, Journal of Interactive Marketing,Vol. 12, No.4, Autumn

Hansen Torben dan Jan Moller Jensen. (2009). "Shopping Orientations and OnlineClothing Purchases: The Role of Gender and Purchase Situation", European Journal of Marketing, Vol. 43, No. 9/10

Hassan et al., (2010) "Influence of Shopping Orientation and Store Image of Patronageof Furniture Store", International Journal of Marketing Studies, Vol.2, No.1, 142

Hassanuddin, “Apa itu Social Shopper Produk Apa yang Mereka Beli”, diaksespada tanggal $27 \quad$ Maret $2012 \quad$ dari http://www.onlinestoreku.com/index.php/component/k2/item/311-apa-itusocialshopper-produk-apa-yang-mereka-beli

Kienan, Brenda. (2001). "Small Bussiness Solutions E-Commerce, E-Commerce untukPerusahaan Kecil”, Elex Media Komputindo: Jakarta.

Kim et al., (2000) "Effects of Consumer Lifestyles on Purchasing Behavior on theInternet: A Conceptual Frameworks and Empirical Validation",International Association for Information Systems Electronic Library (AISeL), p. 76

Kotler, Philip. (2009). “Manajemen Pemasaran”, Edisi 12, Jilid 1, PT. Indeks 
Kotler dan Armstrong. (2010). "Principles of Marketing”, Pearson Prentice Hall, NewYork.

Korgaonkar dan Silverblatt. (2003). "Relationship of Type of Product, Shopping Orientations and Demographics with Preference for Shopping in the Internet", Journal of Business and Psychology, Vol. 18, No.1

Lim et al., (2010). "Online Search and Buying Behavior: Malaysian Experience", Canadian Social Science, vol. 6, No.4

Magie, Anna Ashlock, (2008). "An Analysis of Lifestyle, Shopping Orientations, ShoppingBehaviors and Shopping Involvement Among Teens Aged 13 to 18 in TheUnited States", ProQuest Dissertations and Theses.

Malhotra, Naresh K., (2004). "Riset Pemasaran: Pendekatan Terapan", Edisi keempat,Jilid 1, PT. Indeks, 2009 Mowen dan Minor, "Perilaku Konsumen", Erlangga, Jakarta.

Prabowo dan Suwarsi, (2009) "Pengaruh Shopping Orientations dan Gender Differences pada Online Information Search dan Online Purchase", Fokus Manajerial,Vol. 7, No. 2.

Primanita dan Amiani, (2009) "Analisa Perilaku Belanja Pria dan Wanita UsiaProduktif”, Manajemen Kepariwisataan Universitas Kristen Petra.

Priyatno, Duwi, (2010) "Teknik Mudah dan Cepat Melakukan Analisis Data PenelitianDengan SPSS”. Penerbit Gaya Media, Yogyakarta.

Punj dan Moore, (2009) "Information Search and Consideration Set Formation in AWeb-based Store Environment", Journal of Business Research, Vol. 62.

Ratomo, "Pembeli Online Paling Minati Fesyen, Kecantikan dan Gadget",diakses pada tanggal $28 \quad$ Februari2017dari http://www.antaranews.com/berita/383507/pembeli-online-paling-inatifesyenkecantikan-dan-gadget

http://www.viva.co.id/cangkang/ramadhan2013/news/read/152786-47-masyarakatpernah-transaksi-online 